ISSN 1991- 8690

website:http://jsci.utq.edu.iq

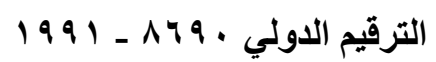

Email|:utjsci@utq.edu.iq

\title{
Isolation and Identification of Three Alkaloids Compounds from Albizia lebbeck \\ L.Leaves and study of Their Antimicrobial Activity Against Pathogenic Bacteria of \\ Urinary Tracts Inflammatory in vitro
}

\author{
Ashwaq Abood Shenta $\quad$ Abbas Dawwas Matter Al-Maliki \\ Chemistry department- Education college of pure sciences \\ Basrah University-Basrah-Iraq.
}

\begin{abstract}
Three alkaloidic compounds are 3,3-dimethyl-4-(1-aminoethyl)- Azetidin-2-one, 2,4-Bis( hydroxylamino)5-nitropyrimidine and 2-Amino-4-hydroxy pteridine-6-carboxylic acid were isolated and purified from Albizia lebbeck L.leaves. Gas chromatography- mass spectrum technique, thin layer chromatography and column chromatography were carried out for identification of chemical structures of these compounds. Antimicrobial activity of the three alkaloids were recorded against pathogenic bacteria of urinary tracts represented by Proteus sp., Klebsiella sp., Pseudomonas aeruginosa, Escherichia coli and Staphylococcus aureus. The highest inhibition zone diameter was measured for the mixture of alkaloidic compounds against Staphylococcus aureus bacteria with value equal to $42 \mathrm{~mm}$ at concentration $150 \mathrm{mg} / \mathrm{ml}$ whereas the highest inhibition zone diameter was recorded for 2-Amino-4-hydroxypteridine-6-carboxylic acid compound against Staphylococcus aureus bacteria with value equal to $23 \mathrm{~mm}$ at the same concentration. Cytotoxicity detection proved that all alkaloid compounds have no toxicity towards red blood cells. Therefore the three alkaloids can be used as medicinal herbal substituents to treat urinary tract Inflammatory instead of antibiotics but this work demands further pharmaceutical and clinical studies.
\end{abstract}

Keywords: Albizia lebbeck L.leaves, Alkaloidic compounds, Medicinal activity, GC-mass spectrum, Cytotoxicity.

$$
\begin{aligned}
& \text { عزل وتشخيص ثلاث مركبات قلويدية من أوراق نبات البرهامي(Albizia lebbeck L) } \\
& \text { ودراسة فعاليتها ضد الجراثيم المرضية لالتهابات المجاري البولية مختبريا }
\end{aligned}
$$

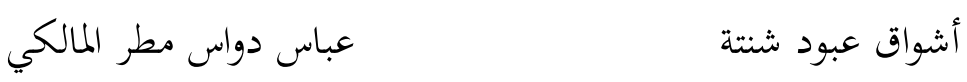

$$
\begin{aligned}
& \text { قسم الكيمياء - كلية التربية للعلوم الصرفة - جامعة البصرة } \\
& \text { البصرة - العراق }
\end{aligned}
$$




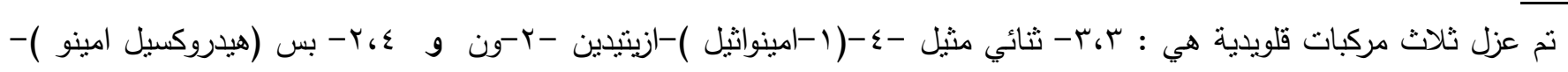

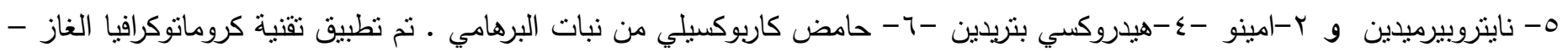 طيف الكتلة و تقنية كروماتوكرافيا الطبقة الرقيقة لنتخيص التراكيب الكيمبائية الدقيقة لهذه المركبات. سجلت الفعالية الضد مايكروبية للقلويدات} Proteus sp., Klebsiella sp., Pseudomonas aeruginosa, Escherichia ( الثلاثة ضد البكتيريا المرضية للمجاري البولية المتمثلة (Staphylococcus aureus و coli ) تم قياس قطر منطقة التثبيط الأعلى لمزيج المركبات القلويدية ضد(Staphylococcus aureus)

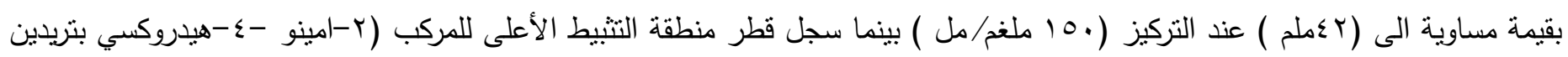
- - - حامض كاربوكسيلي ) والذي سجل ضد بكتيريا (Staphylococcus aureus ) بقيمة مساوية الى (rrملم) عند نفس التركيز . أنثبت كثف السمية الخلوية بأن جميع المركبات القلويدية لا تمنلك أي تاثثر سمي تجاه كريات الدم الحمراء ولذلك فأن المركبات القلويدية الثناثة يمكن ان تستعمل كبدائل عثبية دوائية لعلاج التهابات المجاري البولية بدلا من المضادات الحياتية لكن هذا العمل يتطلب المزيد من الدراسات السريرية والصيدلانية.

\section{Introduction}

Pathogenic bacteria have developed resistance against existing antibiotics due to indiscriminate use of antimicrobial drugs to treat the infectious diseases $(1,2)$. The worldwise emergence of Escherichia coli, Klebsiella pneumoniae, Staphylococcus aureus and many other $\beta$-lactamase producers have become a major therapeutic problem. Multi-drug resistant strains are widely distributed in hospitals and are increasingly being isolated from community acquired infections (3).

Infectious diseases are the leading cause of death worldwide. The clinical efficacy of many existing antibiotics is being threatened by the emergence of multi-drug resistant pathogens (4). Bacterial and fungal pathogens have evolved numerous defence mechanisms against antimicrobial agents and resistance to old and newly produced drugs is on the rise (5). Antibiotics are sometimes associated with side effects whereas there are some advantages of using antimicrobial compounds of medicinal plants, such as often fewer side effects, better patient tolerance, relatively less expesive, acceptance due to long history of use and being renewable in nature(6). Antibacterial constituents of medicinal plants and their use for the treatment of microbial infections as possible alternatives to synthetic drugs to which many infections microorganisms have become resistant seem to very much promising(7). Due to the cost effectiveness, safety, increasing failure of chemotherapy and antibiotic resistance exhibited by pathogenic microbial agents, the search for plant products has increased for their potential antimicrobial activity(8). Typical alkaloids are derived from plant source, they are basic compounds contain one or more nitrogen atoms(usually in a hetrocyclic ring) and they have marked physiological effects on human or animal, also alkaloide molecule must contain nitrogen connected to at least two carbons atoms, and have at least one ring $(9,10)$. Alkaloids are particularly common in certain families such as Fabaceae, Liliaceae, Ranunculaceae, Apocynaceae, Solanceae and Papaveraceae. Plant alkaloids usually have profound physiological action in human with nervous system effects being the most prominent (11). The medicinal importance of alkaloidic compounds results from their antimicrobial properties and its ability to bind with different enzymes and nucleic acid, then destruct of metabolism of carbohydrates, lipids and proteins(12,13), next the alkaloids have therapeutics features for numerous diseases(14), therefore the presence of bioactive compounds including alkaloids are normally accumulated as 
secondary metabolites in all plants cells but their concentration varies according to the plant parts, season, climate and particular growth phase. The leaf is one of the highest accumulatory plant parts of such compounds and people are generally preferred it for therapeutic purposes. Some of the active compounds such as a alkaloids inhibit the growth of disease causing microbes either singly or in combination $(15,16)$.

Albizia lebbeck belongs to family Mimosaceae, commonly known as women's tongue tree. It is native tropical southern Asia, is a large, erect, unarmed, deciduous spreading tree found throughout India and has be used in Ayurveda, Sidha and Unani medicines. Albizia species is reported to have many important medicinal properties mainly anti- inflammatory and analgesic properties. Decoction of the leaves and barks were used in cold and cough, respiratory problems and against bronchial asthma. The plant extracts were investigated against allergic rhinitis $(17,18)$. Many studies ensured presence of saponins, tannins, alkaloids, phenols and glycosides in Albizia lebbeck plant (19). Therefore this study aimed to investigate the medicinal effect of alkaloidic compounds isolated from the leaves of this medicinal plant against pathogenic bacteria of urinary tracts.

\section{Materials and Methods}

\section{Plant collection}

Albizia lebbeck leaves were collected from Abu AL- Khaseeb region farms, in Basrah governorate, southern of Iraq, cleaned with cold distilled water, dried in the shadow at room temperature, grinded, powdered and kept in dark plastic containers until of use. The plant was taxonomied in biology department at college of education for pure sciences in Basrah University.

\section{Chemicals}

All chemicals are of analytical grade and were supplied as the following Ethanol, acetic acid, $\alpha$-naphthol, sulphuric acid, ferric chloride, bismuth sub-nitrate, potassium hydroxide, ninhydrine, ammonium hydroxide, chloroform, mercuric chloride, potassium iodide, sodium citrate, sodium carbonate, copperic sulphate and benzene.

\section{Culture medium}

Muller-Hinton Agar medium was prepared according to information determining by manufacturing company and it was supplied from biology department in Education College for pure sciences at university of Basrah.

\section{Pathogenic Bacteria}

Pathogenic bacterial strains of urinary tracts were isolated from some patients in general Basrah hospital then identified represented by Proteus sp., Klebsiella sp.,Pseudomonas aeruginosa, Escherichia coli ( negative towards Gram stain) and Staphylococcus aureus ( positive towards Gram stain).

\section{Isolation of Alkaloids from Albizia lebbeck leaves}

Twenty five grams of powdered leaves of Albizia lebbeck were mixed with $250 \mathrm{ml}$ of (10\%) ethanolic acetic and the mixture was stirred on magnetic stirrer for $24 \mathrm{hr}$ then it was filtered by Buchner funnel. The filtrate was concentrated to quarter of its volume by rotary evaporator and was basified with ammonium hydroxide to $\mathrm{pH}$ equal to 9. The extraction process was achieved by separation funnel by adding $(3 \times 20 \mathrm{ml})$ of chloroform then alkaloids were extracted and dried (20) with yield equal to $1.6 \mathrm{gm}$.

\section{Preliminary qualitative tests}

Isolated Alkaloids were underwent to several tests such as:

1- Alkaloids test: was carried out by using Dragendroff reagent (21).

2- Carbohydrates test: was done by using Molish reagent (22).

3- Phenols test: was carried out by using (1\%) ferric chloride (23).

4- Glycosides test: was made by using Benedict reagent (22).

5- Saponin test: was done by using (5\%) mercuric chloride (21). 
6-Amino acids test: was made by using ninhydrine reagent (22).

\section{Thin Layer Chromatography (TLC)}

TLC technique was used for separation of alkaloids compounds and determination of their purity. One hundred microliters of alkaloids extract was toulerenced on silica gel plate $(2 \times 10 \mathrm{~cm})$ and was put in glass jar then BAW ( $n$ - butanol:acetic acid: distilled water ) solvent was used as eluent system with ratio equal to (1.5:1.5: 7) V/V/V for $30 \mathrm{~min}$. The glass plate was dried and the components were developed by UV- lamp at 233 $\mathrm{nm}$, Dragendroff reagent and iodine vapour (24). Rates of flow $\left(R_{f}\right)$ values were measured for each alkaloids compound.

\section{Gas Chromatography (GC)- Mass spectrum technique of alkaloids}

GC- mass spectrum technique was achieved in Agriculture College at university of Basrah for separation all alkaloids compounds and identification of their chemical structures (25).

\section{Column Chromatography of alkaloids}

Column chromatography (CC) technique was carried out to separate each alkaloidic compound by using a column has length and diameter equal to $22 \mathrm{~cm}, 1 \mathrm{~cm}$ respectively. The glass wood put in the down end of column and was filled with silica gel $\mathrm{C}_{60}$ (230-180 mesh) then BAW was used as an eleunt (26).

\section{Thin Layer Chromatography of alkaloids compound}

TLC technique was used after column chromatography for measurment of rates of flow $\left(\mathrm{R}_{\mathrm{f}}\right)$ for each alkaloids compound separated from column (24).

\section{Antimicrobial activity measurement of alkaloids and determination of maximal and minimal inhibitory concentration}

Various concentrations of isolated alkaloids extract $(25,50,75,100,125,150,175 \mathrm{mg} / \mathrm{ml})$ were used to investigate the maximal inhibitory concentration against growth of pathogenic bacteria of urinary tracts, they were Proteus sp., Klebsiella sp., Pseudomonas aeruginosa, Escherichia coli and Staphylococcus aureus for determination of antimicrobial activity of the maximal inhibitory concentration(Max IC) and we founded it equal to $150 \mathrm{mg} / \mathrm{ml}$ by using MuellerHinton Agar as a culture medium depending on diffusion method by petri dishes which after that they were incubated in the incubator for $24 \mathrm{hr}$. Finally the inhibition zone diameters were recorded (25). Also this method was used for each alkaloids compounds separated by column at the same concentration $(150 \mathrm{mg} / \mathrm{ml})$.

The same method used to determine the minimal inhibitory concentration(MIC) by using series of diluted concentration of alkaloids isolated extract and found that the minimal inhibitory concentration are as follows $(15,20,5,15$ and 30 $\mathrm{mg} / \mathrm{ml}$ ) against Staphylococcus aureus, Klebsiella sp., Escherichia coli , Pseudomonas aeruginosa and Proteus sp. bacteria respectively.

\section{Determination of cytotoxicity of alkaloids compounds}

Cytotoxicity of isolated alkaloids from Albizia lebbeck leaves was determined to investigate the anti-activity of urinary tracts bacteria. Series of concentrations for alkaloids compounds, were prepared,where $2000 \mathrm{mg}$ was dissolved in $10 \mathrm{ml}$ of Ringer's solution then it was diluted with following ratios $(1: 1,1: 10,1: 100$, $1: 1000 \mathrm{v} / \mathrm{v})$.Negative control factor was used ,contains Ringer's solution which was (normal saline) and positive control factor was used ,contains tap water. After that $(0.8 \mathrm{ml})$ of each concentration was put in a sterilized test tube type (Eppendrof tube) contains an anti-clouting substance then to each tube , $0.2 \mathrm{ml}$ of blood was added, the total volume in each tube became $(1 \mathrm{ml})$ .The tubes were incubated in the incubator at $\left(37^{\circ}\right.$ C) for (30min) with speed equal to (3000 rpm).Finally all tubes were tested to observe hemolysis(27). 


\section{Results and Discussion}

In the current study, alkaloids extract was isolated and purified with extraction percentage equal to $(6.4 \%)$. Table (1) indicates the chemical qualitative analysis of alkaloids isolated from Albizia lebbeck leaves. The results show presence of alkaloids only but carbohydrates, glycosides, phenols, saponins and amino acids were not found.
It is known that alkaloids are abundant in many medicinal plant including Albizia lebbeck $(17,19)$. The biochemical advantage of presence of alkaloids in medicinal plant is isolation of toxic materials from plant, storage of some essential elements such as nitrogen, regulators of growth and protection of plant from attack of fungi and insects (28).

Table (1) preliminaryqualitative tests for isolated alkaloids from Albizia lebbeck leaves.

\begin{tabular}{|l|c|l|l|}
\hline \multicolumn{1}{|c|}{ Test } & Test result & \multicolumn{1}{c|}{ Notes } & \multicolumn{1}{c|}{ Conclusions } \\
\hline Dragendroff & + & $\begin{array}{l}\text { Formation of orange } \\
\text { precipitate }\end{array}$ & Presence of alkaloids \\
\hline Molish & - & No violet ring & No carbohydrates \\
\hline Benedict & - & No red precipitate & No glycosides \\
\hline $\mathrm{FeCl}_{3}(1 \%)$ & - & No blusich-green colour & No phenols \\
\hline $\mathrm{HgCl}_{2}(5 \%)$ & - & No white precipitate & No saponins \\
\hline Ninhydrin(1\%) & - & No violet colour & No amino aids \\
\hline
\end{tabular}

Table (2) represents thin layer chromatography (TLC) results of alkaloids extracted from Albizia lebbeck. There spots were separated have rates of flow $\left(\mathrm{R}_{\mathrm{f}}\right)$ values equal to $0.32,0.48$ and 0.62 this ensures presence of three alkaloidic compounds in the extract and these components were tested and developed by
Dragendroff reagent as a qualitative and characteristic developer for alkaloids, also by using iodine vapour the alkaloids separated showed brown colour and by using litmus paper, the colour has changed from red to blue, therefore, this ensures that these compounds are nitrogenous having basic features $(29,30)$.

Table(2) TLC results of isolated alkaloids from Albizia lebbeck leaves.

\begin{tabular}{|c|c|c|c|c|}
\hline Eluent system & Reagents & Spots No. & $\begin{array}{c}\text { Flow } \\
\text { rates }\left(\mathbf{R}_{\mathbf{f}}\right) \text { values }\end{array}$ & Conclusions \\
\hline \multirow{2}{*}{$\begin{array}{c}\text { BAW } \\
\text { (n-butanol:acetic } \\
\text { acid: distilled water }) \\
(1.5: 1.5: 7) \mathrm{V} / \mathrm{V} / \mathrm{V}\end{array}$} & Eyes & 3 & $0.62,0.48,0.32$ & Pure compounds \\
\cline { 2 - 5 } & $\mathrm{I}_{2}$-vapour & 3 & $0.62,0.48,0.32$ & $\begin{array}{c}\text { Presence of } \\
\text { nitrogenous } \\
\text { organic } \\
\text { compounds }\end{array}$ \\
\cline { 2 - 5 } & Dragendroff & 3 & $0.62,0.48,0.32$ & $\begin{array}{c}\text { Presence of } \\
\text { alkaloids }\end{array}$ \\
\hline
\end{tabular}


The results of gas chromatography (GC) mass spectrum technique was used successfully in this study to isolate the three alkaloids compounds which were separated in TLC chromatography. GC technique showed the three peaks (A, B and C) of the each alkaloidic compound with their retention times equal to $18.390 \mathrm{~min}, 21.100 \mathrm{~min}$ and 21.599 min then mass spectrum depending GC was recorded for each alkaloidic compound. The spectrum of first separated compound (peak No.1) indicated presence of 2-one-3, 3-dimethyl-4-(1aminoethyl) Azetidin compound. The spectrum of second separated compound (peak No.2) showed presence of 2, 4-Bis(hydroxylamino)-5nitropyrimidine compound and the mass spectrum of the third separated compound(peak No.3) indicated presence of 2-Amino-4hydroxypteridine-6-carboxylic acid compound. These peaks of alkaloids compound are represented in the chromatogram in figure (1), and the mass spectra of the three alkaloids compounds are shown in the figures $(2,3$ and 4).

Column chromatography $(\mathrm{CC})$ technique separated each alkaloids compounds alone with times equal to $13 \mathrm{~min}, 20 \mathrm{~min}$ and $22 \mathrm{~min}$ with volumes equal to $0.3,0.4$ and $0.3 \mathrm{ml}$ respectively then TLC results of alkaloids compounds (separated from column) indicated that the 2-one3,3-dimethyl-4-(1-aminoethyl)Azetidin compound has rate of flow $\left(R_{f}\right)$ equal to 0.32 , the 2,4Bis(hydroxylamino)-5-nitropyrimidine compound has rate of flow $\left(\mathrm{R}_{\mathrm{f}}\right)$ equal to 0.48 and the 2-Amino4-hydroxypteridine-6-carboxylic acid compound has rate of flow $\left(R_{f}\right)$ equal to 0.62 . The results of TLC before column chromatography were corresponded with $\mathrm{R}_{\mathrm{f}}$ values after separation using column as show in table (3). This ensures that alkaloids compounds were pure. The GC technique depending on mass spectrum is very fast, characteristic, qualitative, quantitative, separation, purification and identification technique therefore the knowledge of chemical structures of alkaloids compounds gives a fantastic step to synthesis of these compounds in laboratory or isolation these alkaloids in high quantities, then use of them as herbal drugs $(31,32)$.

Table (3): TLC results of alkaloids compounds after using column chromatography

\begin{tabular}{|c|c|}
\hline $\begin{array}{c}\text { Alkaloidic } \\
\text { compounds }\end{array}$ & $\begin{array}{c}\text { Rate of flow } \\
\text { values }\left(\mathbf{( R}_{\mathbf{f}}\right)\end{array}$ \\
\hline A & 0.32 \\
\hline B & 0.48 \\
\hline C & 0.62 \\
\hline
\end{tabular}

A=3,3-dimethyl-4-(1-aminoethyl) Azetidin-2-one, $\mathbf{B}=2$,4-Bis(hydroxylamino)-5-nitropyrimidine and $\mathbf{C}=$ 2-Amino-4-hydroxypteridine-6-carboxylic acid. 


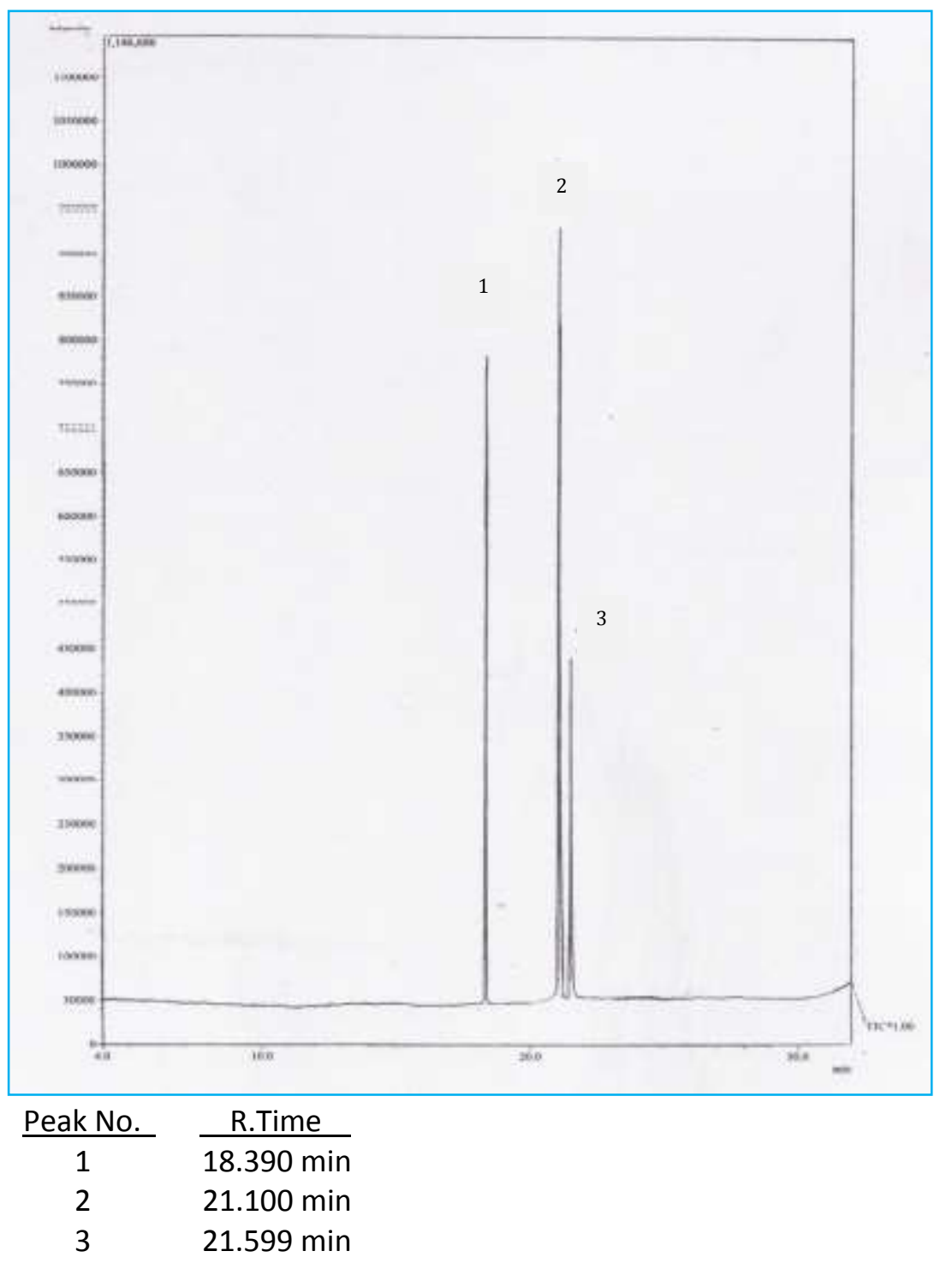

Figure (1) Chromatogram of the alkaloids compounds separated by gas chromatography 
Line \#1 R.Time:18.390 min $\mathrm{SI}=95$ Formula:C7H14N2O MolWeight :142

Comp.Name: 3,3-dimethyl-4-(1-aminoethyl)-azetidin-2-one

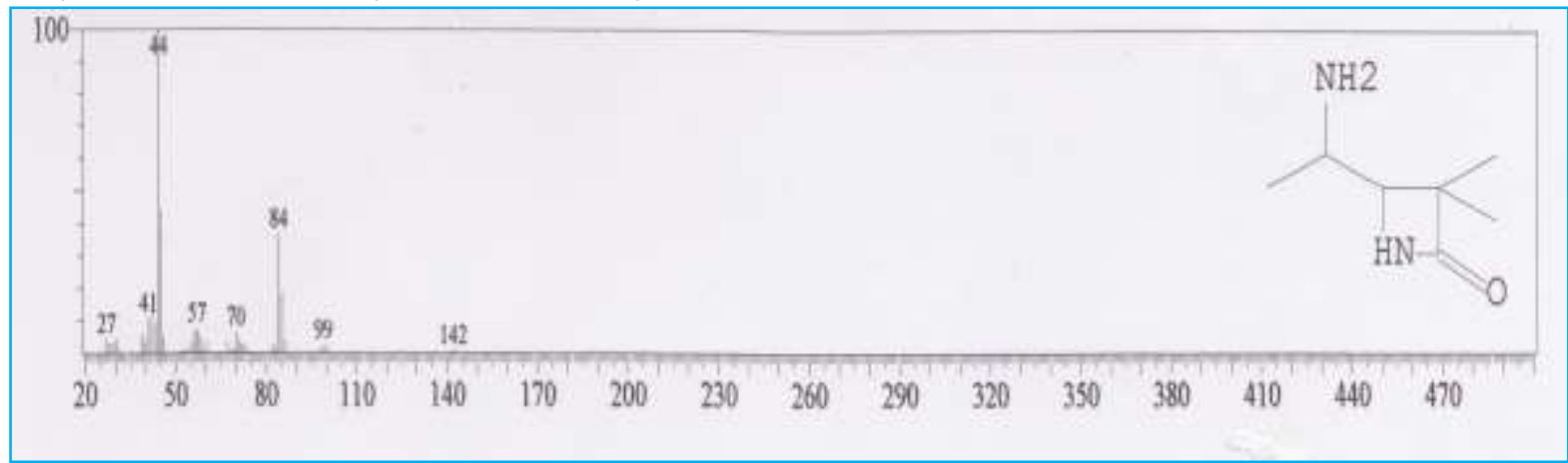

Figure (2): Mass spectrum of 3,3-dimethyl-4-(1-aminoethyl)-azetidin-2-one compound (peak No.1) separated by GC technique and its chemical structure.

Line \#2 R.Time: $21.100 \mathrm{~min}$

$\mathrm{SI}=91$ Formula:C4H5N5O4 MolWeight :187

Comp.Name: 2,4-Bis(hydroxylamino)-5-nitropyrimidine

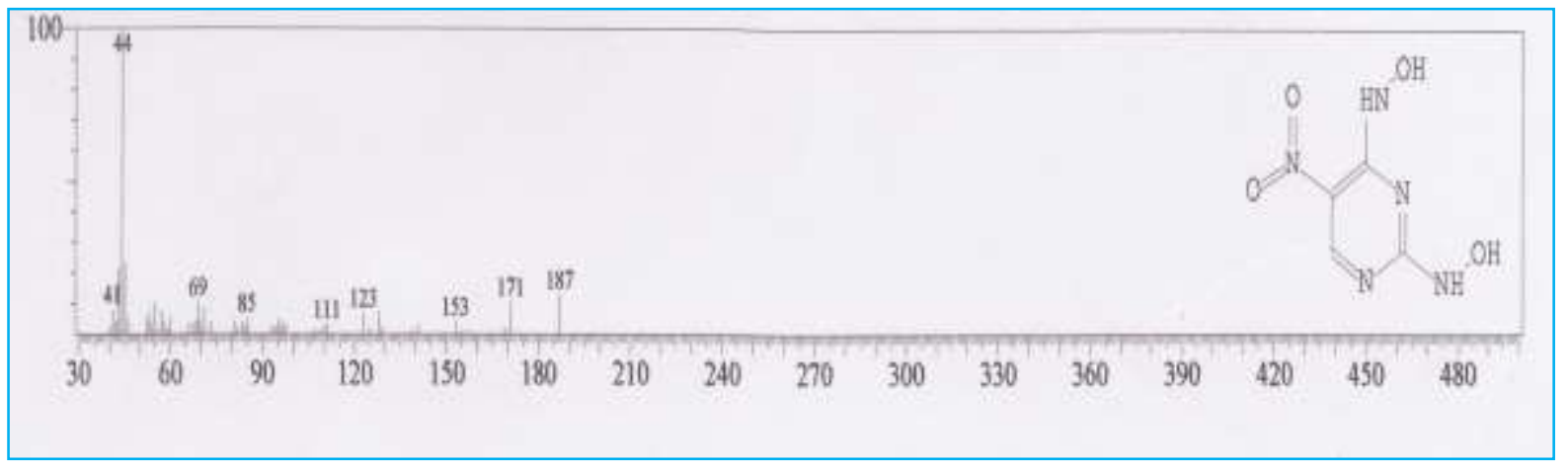

Figure(3): Mass spectrum of 2,4-Bis(hydroxylamino)-5-nitropyrimidine compound (peak No.2) separated by GC technique and its chemical structure .

Line \#3 R.Time: $21.599 \mathrm{~min}$

$\mathrm{SI}=96$ Formula:C7H5N5O3 MolWeight :207

Comp.Name:2-Amino-4-hydroxypteridine-6-carboxylic acid

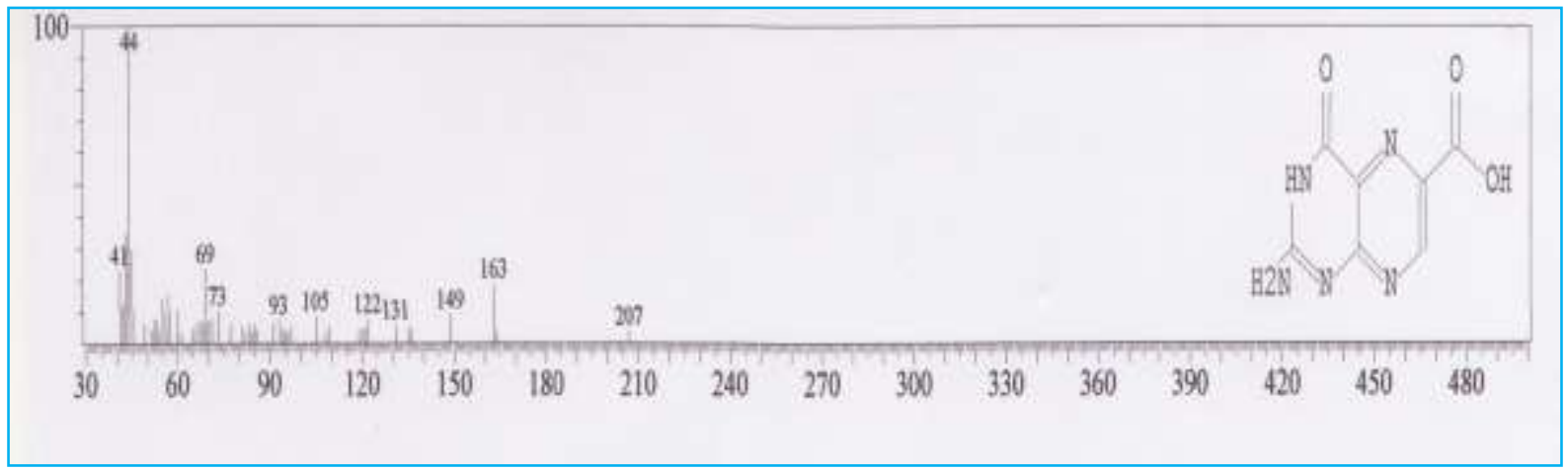

Figure (4): Mass spectrum of 2-Amino-4-hydroxypteridine-6-carboxylic acid compound (peak No.3) separated by GC technique and its chemical structure. 
There are several advantages and properties to use the column in separation of alkaloids, are accuracy, purity, size of alkaloids molecule, determination nearly the molecular weight and finally identification. The presence of structural and functional groups in these alkaloids also determine which of them is separated first, next the polarity of alkaloids compound also is an important factor in separation Process by column chromatography technique $(33,34)$.

Table (4) indicates that the antimicrobial activities of the alkaloids extract isolated from Albizia lebbeck $L$. leaves by using various concentrations $(25,50,75,100,125,150$ and
$175 \mathrm{mg} / \mathrm{ml}$ ). It was observed that increase of alkaloids extract concentration led to inhibit all pathogenic bacteria of urinary tracts, but generally the inhibitoriest activity was for the concentration (150 $\mathrm{mg} / \mathrm{ml}$ ) against Staphylococcus aureus bacteria. The inhibition zone diameters were 42 $\mathrm{mm}, 25 \mathrm{~mm}, 26 \mathrm{~mm}, 31 \mathrm{~mm}$ and $21 \mathrm{~mm}$ against Staphylococcus aureus, Klebsiella sp., Escherichia coli, Pseudomonas aeruginosa and Proteus sp. bacteria respectively at concentration $150 \mathrm{mg} / \mathrm{ml}$. The maximal inhibitory concentration was measured to be $150 \mathrm{mg} / \mathrm{ml}$ which was recorded against Staphylococcus aureus bacteria.

Table (4): The results of antimicrobial activity of alkaloids extract isolated from Albizia lebbeck leaves.

\begin{tabular}{|c|c|c|c|c|c|}
\hline \multirow{2}{*}{$\begin{array}{c}\text { Conc. of alkaloids } \\
\text { extract (mg/ml) }\end{array}$} & $\begin{array}{c}\text { Inhibition zone diameter }(\mathbf{m m}) \\
\text { Staphlococcus } \\
\text { aureus }\end{array}$ & $\begin{array}{c}\text { Klebsiella } \\
\text { sp. }\end{array}$ & $\begin{array}{c}\text { Escherichia } \\
\text { coli }\end{array}$ & $\begin{array}{c}\text { Pseudomonas } \\
\text { aeruginosa }\end{array}$ & $\begin{array}{c}\text { Proteus } \\
\text { sp. }\end{array}$ \\
\hline 150 & 42 & 25 & 26 & 31 & 21 \\
\hline 125 & 40 & 23 & 23 & 28 & 20 \\
\hline 100 & 36 & 20 & 23 & 24 & 20 \\
\hline 75 & 31 & 16 & 20 & 19 & 18 \\
\hline 50 & 25 & 12 & 16 & 15 & 14 \\
\hline 25 & 20 & 9 & 15 & 12 & 11 \\
\hline
\end{tabular}

Table (5) indicates that the minimal inhibitory concentration values (MIC) of alkaloids extract against pathogenic bacteria of urinary tracts. It was noticed that the concentrations were $(15,20,5,15$ and $30 \mathrm{mg} / \mathrm{ml}$ ) against Staphylococcus aureus,
Klebsiella sp., Escherichia coli, Pseudomonas aeruginosa and Proteus sp. bacteria respectively. The Pseudomonas aeruginosa bacteria recorded the less minimal inhibitory concentration among all pathogenic bacteria (35).

Table (5) : The minimal inhibitory concentration values of alkaloids extract against pathogenic bacteria

\begin{tabular}{|c|c|}
\hline pathogenic bacteria & $\begin{array}{c}\text { The minimal inhibitory } \\
\text { conc.(mg/ml) }\end{array}$ \\
\hline Staphylococcus aureus & 15 \\
\hline Klebsiella sp. & 20 \\
\hline Escherichia coli & 5 \\
\hline Pseudomonas aeruginosa & 15 \\
\hline Proteus sp. & 30 \\
\hline
\end{tabular}


Different studies indicated that alkaloids compounds activity of the medicinal plants towards growth of microbial organisms especially negative and positive pathogenic bacteria, because the alkaloids have physiological effects and dramatic medicinal features for treatment of various disease including urinary tracts inflammatory $(36,37,38)$. The biochemical mechanism of alkaloids activity is represented by chemical bonding between these active compounds with nucleic acids(DNA and RNA), then inhibition of metabolism of these acids(12,13). In the cell of microorganism including pathogenic bacteria, the alkaloids denaturate the cell proteins and they act an interaction which enzymes of protein biosynthesis containing thiol group (-SH). Also alkaloids compounds are capable of linking with enzyme at protein metabolism such as DNApolymerase, DNA- ligase and RNA- polymerase (28.39).

It was noticed that the antimicrobail activity towards Positive Gram Stain bacteria (Staphylococcus aureus) was higher than negative Gram stain bacteria (Proteus sp., Klebsiella sp., Pseudomonas aeruginosa, Escherichia coli) because the Positive Gram Stain bacteria have dense lipidic layers cause a disorder in permeability of active chemical compounds including alkaloidic to living cell but the negative Gram stain bacteria have less lipidic layers $(12,13)$. The minimal inhibitory concentrations were 15, 20, 5,15 and $30 \mathrm{mg} / \mathrm{ml}$ against Staphylococcus aureus, Klebsiella sp., Escherichia coli, Pseudomonas aeruginosa and Proteus sp., bacteria respectively. The functional group in alkaloid is imine group ($\mathrm{N}=\mathrm{C}-$ ) which has ability to decompose and destruct the cell of pathogenic bacteria (13, 17).

The results of antimicrobail activity of the inhibition zone diameters for2-Amino-4hydroxypteridine-6-carboxylic acid compound against Staphylococcus aureus, Klebsiella sp., Escherichia coli, Pseudomonas aeruginosa and Proteus sp. bacteria were 23,12,11, 15 and 13 $\mathrm{mm}$ respectively at concentration $(150 \mathrm{mg} / \mathrm{ml})$ and for 2,4-Bis(hydroxylamino)-5-nitropyrimidine against Staphylococcus aureus, Klebsiella sp., Escherichia coli , Pseudomonas aeruginosa and Proteus sp. bacteria were $18,11,10,14$ and 0 but for 3,3-dimethyl-4-(1-aminoethyl) Azetidin 2one compound against the same bacteria were 16 , $8,9,0$ and 7 at the same concentration. It was noticed that the alkaloids extract have a higher activity towards pathogenic bacteria than each alkaloidic compound, the reason for this belongs to synergistic interaction between all three alkaloidic compound leading to increase of antimicrobail activity(17).

The compound A(3,3-dimethyl-4-(1aminoethyl) Azetidin 2-one) was the highest inhibition zone diameter against Staphylococcus aureus bacteria and the compound $\mathbf{B}(2,4-$ Bis(hydroxylamino)-5-nitropyrimidine) was the highest inhibition zone diameter against Staphylococcus aureus bacteria also The compound C(2-Amino-4-hydroxypteridine-6carboxylic acid) was the greater inhibition zone diameter against Staphylococcus aureus bacteria. The reason for this is because this alkaloidic compounds have multi function groups such as hydroxyl group ,carbonyl group ,carboxylic acid group, $\mathrm{NH}_{2}$ group and $\mathrm{NO}_{2}$ group and imine group ( $-\mathrm{N}=\mathrm{C}-$ ) which that have a higher activity towards Staphylococcus aureus bacteria have dense lipidic layers cause a disorder in permeability of active chemical compounds including alkaloidic to living cell of pathogenic bacteria (40).

Table (6) shows the results of inhibition zone diameters values of alkaloidic compounds at the maximal inhibitory concentration $(150 \mathrm{mg} / \mathrm{ml})$. The diameters recorded were $(16,8,9,0$ and 7 )mm , (18, 11, 10, 14 and 0) $\mathrm{mm}$ and ( $23,12,11$ ,15 and 13) $\mathrm{mm}$ for A, B and C compounds against Staphylococcus aureus, Klebsiella sp., Escherichia coli, Pseudomonas aeruginosa and Proteus sp. bacteria respectively. 
Table (6) Antimicrobail activity of each alkaloidic compound (concentration= 150 $\mathrm{mg} / \mathrm{ml}$ ) separated from Albizia lebbeck leaves.

\begin{tabular}{|c|c|c|c|c|c|}
\hline \multirow{2}{*}{$\begin{array}{c}\text { alkaloidic } \\
\text { compound }\end{array}$} & \multicolumn{5}{|c|}{ Inhibition zone diameter(mm) } \\
\cline { 2 - 6 } & $\begin{array}{c}\text { Staphylococcus } \\
\text { aureus }\end{array}$ & $\begin{array}{c}\text { Klebsiella } \\
\text { sp. }\end{array}$ & $\begin{array}{c}\text { Escherichia } \\
\text { coli }\end{array}$ & $\begin{array}{c}\text { Pseudomonas } \\
\text { aeruginosa }\end{array}$ & $\begin{array}{c}\text { Proteus } \\
\text { sp. }\end{array}$ \\
\hline A & 16 & 8 & 9 & - & 7 \\
\hline B & 18 & 11 & 10 & 14 & - \\
\hline C & 23 & 12 & 11 & 15 & 13 \\
\hline
\end{tabular}

$\mathbf{A}=3,3$-dimethyl-4-(1-aminoethyl) Azetidin 2-one, $\mathbf{B}=2$,4-Bis(hydroxylamino)- 5-nitropyrimidine and $\mathbf{C}=2$ Amino-4-hydroxypteridine-6-carboxylic acid.

The cytotoxicity results of alkaloids extract are shown in table (7). It was observed that the alkaloids isolated from Albizia lebbeck plant have no cytotoxicity because they did not show any hemolysis towards red blood cells, this makes use of this extract is safe for treating the urinary tracts inflammatory

(38).

\section{Table (7) :Cytotoxicity results of isolated alkaloids from Albizia lebbeck leaves}

\begin{tabular}{|c|c|}
\hline $\begin{array}{c}\text { Conc. of alkaloids extract } \\
(\mathbf{m g} / \mathbf{m l})\end{array}$ & Hemolysis \\
\hline 100 & - \\
\hline 20 & - \\
\hline 2 & - \\
\hline 0.2 & - \\
\hline
\end{tabular}

- : no hemolysis

\section{Conclusion}

The isolated alkaloids from leaves have high antimicrobail activity towards pathogenic bacteria of urinary tracts infection since gave more inhibition zone diameters this means that alkaloids have a great ability to kill all represented bacteria. Therefore that alkaloids can be used as herbal substituent for treatment the infections of urinary tracts instead of antibiotics.

\section{References}

1-Dadrie, L.Z ; Jacob, B.;Anandan, R.;Rajkapoor, B. and Ulla, R.M.(2009). Antibacterial activity of ethanolic extract of Indonessiell echiodes $L$. ness evaluated by the filter paper disc method. Pak. J. pharm.Sci,22: 123-125.

2-Davis,J.(1994). Inactivation of the antibiotics and the dissemination of resistance gene. Science, 264:375-382.

3-Maji,S.;Dandapat, P.; Ojha,D.; Mity,C.;Halder, S.K.; Das Mohapatra, P. K.; Pathak, T. K.;Pati, B..;Samanta,A. and Mondal, K.C.(2010). In vitro antimicrobial potentialities of different solvent extracts of Extracts of Ethnomedicinal plants against clinically isolated human pathogens.J.Phytology, 2(4):57-64. 
4-Bandow, J.E; Brotz, H.; Leichent, L.T.O.; Labischinski,H. and Hecker, M.(2003). Proteomic approach to understanding antibiotic action. Antimicro. Agents. Chemotherap. , 47:948-955.

5-Scazzocchio, F.; Comets, M.F.;Tomassini,L. and Palmery, M.(2001). Antibacterial activity of Hydrastic candensis extract and its major isolated alkaloids. Planta. Med., 67:561563.

6-Reddy, L.J. and Jose, B.(2010). Evaluation of antibacterial activity of the bark, flower and leaf extracts of Gliricidia Sepium from south India.Int.J. of current pharm. Res., 2(3):18-20.

7-Bari, M.A.; Islam, W.; Khan, A.R. and Manadal, A.(2010). Antibacterial and antifungal activity of Solanum toruum (Solanaceae).Int.J. Of Agriculture and biology, 12:386-390.

8-Hammer, K. A.; Carson, C. F. and Riley, T.V.(1999). Antimicrobial activity of essential oils and other plant extracts, J. of Applied Microbio., 86:985-990.

9-Al-Maliki, A.D.M.(2011).Isolation and Identification of an alkaloidic compound from Coriandrum sativum seeds and study of its Medicinal activity against pathogenic bacteria of urinary tracts J. of Basrah Res.(science). 7(2):121-129.

10-Willard, T.(1992). Textbook of advanced herbology. Wild Rose collge of Natural Healing. Alberta.

11-Bradly, P.(1992). British herbal compendium, vol.1, Br. Herb.Med.Assn., London,UK.

12-Jayasurriya, H.; Nupharan, M.K.;Geahlen, R.L.; M clanghlin, J.L. and Chang, C.J.(1991). Emodine, a proteinkinase inhibitor from polygonam Cusp., J.Nat.prod., 55(5): 696703.

13-Cowan, M.M.(1999).Plant products as antimicrobial agents, Clin. Microb.Rev., 124:1811-1821.

14-Bruneton, J.(1995). Pharma cognosy photochemistry medicinal plants. Lavoisier pubs. Paris,France.
15-Pattnaik, S. and Shama, G.D. (2004). Antimicrobial nature of some common and indigenous plant extracts. J.sci. Technol., 16:7-10.

16-Alviano, D.S. and Alviano, C.S. (2009). Plant extracts; search for nw alternatives to treat microbial diseases. Curr.Pharm. Biotechnol., 10:106-112.

17-Uma, B.B.; Prabha kar, K.; Rajendran, S.and Lakshmi, Y.(2009).Antimicrobial activity of Albizzia lebbeck benth against infectios diarrhea.J. microb., 16:26-32.

18-Besra, $\quad$ S.E; $\quad$ Gomes,A.;Chaudhary, L.; Vedasiromoni, J.R and Ganguly, D.K. (2002).Antidiarrhoeal activity of seed extract Albizzia lbbeck studies on conventional rdnt modeles of diarrhea, phytotherapy Res., 16:529-530.

19-El- Mousallamy, A.M.D.(1998). Leaf flavonoids of Albizzia lbbeck. Phytochemical methods. $2^{\text {nd }}$ ed., Chapman and Hall, London, UK.

20-Harborne;J.(1984).Phytochemical methods. $2^{\text {nd }}$. d.,Chapmaqm and Hall, London, UK.

21-Harbone, J. and Baxter, H.(1993). Phytochemical dictionary. Taylor and Francis, London, UK.

22-Harbome, J.(1974). Phytochemical methods. $1^{\text {st }}$. ed.Chapman and Hall, New York, U.S.A.

23-Al- Maliki, A.O.M.(2008).Investigation of biochemical effect of phenols extract isolated from Coriandrum satvum seeds against Echinococcus granulossus parasite in vitro. J.Thi- Qar sci., 1(1):2-9.

24-Fenny, P.(1998). Inhibitory effects of oak leave tanins on the hydrolysis of proteins by trypsin. J. phytochem., 8:2116-2122.

25-Clareria, L.; Berkov,S.; Jalregui, O.; Caujape, J.; Viladomat, F.;Codina, C. and Bastida, J.(2010). Metabolic profiling of Bioactive Pancratium canariense Extracts by GC.MS. phytochemical Analasis. 2010,21, 80-81.

26-Slvakumari ,S., P and Britto, D. A.(2007). Bactericidal activity of La genandra ovato 
(Linh.) Thw. Rhizome oil. Natural product Radiance, vol. 6(5), 2007, pp382-385.

27-Xian-guo, H. and Ursula, M.(1994). Antifungal compound from Solanun nigrscens. J. Ethnopharmocol., 43:173177.

28-Borner, J. and Varner, J.(1965). Plant biochemistry. Academic press. $1^{\text {st }}$. ed. , New York, USA.

29-Goodwin, T. and Mercer, E.(1983). Introduction to plant biochemistry. $2^{\text {nd }}$.ed., Pergamon press ,Oxford, UK.

30-Agrawal, P.K. and Singh, B.(1991). Chemical constituents of Albizzia lebbeck. Indian J.P harma. Sci., 53:24-26.

31- Shashidar ,N.S. (2002). Studies on bioactive natural compounds for their antimicrobial and antioxidant properties in Ph.D. thesis Dept. Of Microbology osmania university Hyderabad.

32- Khan, M. (2010). Biology activity and Phytochemical study of selected Medicinal Plants in Ph.D. thesis Dept. of plant sciences, Quaid-i- Azam university, Islamabad.

33-Back, S. and Liang, J.,(2005). Production of cyanophycian from blue green algae.J.Yong. in vest., 13:56:62.

34-El-Hawary, S.; EL-Fouly, K., and Talaat, Z. (2011). Aphytochemical profile of Albizia lebbeck(L.) Bench. Cultirated in Egypt. Asian Journal of Biochemistry, 6:122-141.

34-Anencini, G. andPerez, C.(1993). Screning of plants used Arginine folk medicine for antimicrobial activity. J. Ethno., 39:119128.

35-Jasmine, R.; Selvakumar, B. N. (2011).Synergistic action of two Indian medicinal plants on clinical isolated of vancomycin resistant Enterococci species .pharmacologyonline 3:1192-1198.

36-Saikat, S. ; Raja, C.H. ; Biplab, D.;Ganesh, H.G. and Subal D.(2010).Analgesic and anti inflammatory herbs: A potential source of modern medicine. Int.J.pharmacy.sci. and Res., vol1 (11): 32-44.
37-Singh, A.; Malhotra, S. and Subban, R.(2008). Anti inflammatory and analgesic agents from Indian medicinal plants. Int. J. of Integrative Biology.3: 57-72.

38-Shah, B.S., Nayak, B.S.;Seth, A.K.; Jalalpure, S.S., Patel, K.N.;Patel,M.A. and Mishra, A.D. (2006).Search for medicinal plants as a source of anti-inflammatory and anti- or thritic agents. Areview. Pharmacognosy Magazine, 2:77-86.

40- Hollman, P.C.; Katan, M.P. (2001). Chlorogenic acid and caffeic acid are absorbed in humans, J. Nutr.131(1):66-71. 